\title{
EVALUATION OF THREE SELECTED POST EMERGENCE HERBICIDES FOR WEED CONTROL ON RICE (Oryza sativa L.) VARIETIES IN JEGA SUDAN SAVANNA ZONE OF NIGERIA
}

\author{
Tanimu, M.U', Alhassan, J2. Yakubu, A. I2. Maishanu H. M. ${ }^{3}$ Muhammad, A. ${ }^{1}$ I. U. Mohammed ${ }^{1}$ Ardo A.M. ${ }^{4}$ Yusuf $^{2}$ \\ $\mathrm{H}^{5}$
}

1. Crop Science Department, Faculty of Agriculture, Kebbi State University of Science and Technology Aliero. Kebbi State Nigeria.

2. Crop Science Department, Faculty of Agriculture, Usmanu Dan Fodiyo University Sokoto, Sokoto State Nigeria.

3. Biological Sciences Department, Faculty of Life Sciences, Usmanu Dan Fodiyo University Sokoto, Sokoto State Nigeria.

4. Department of Forestry, College of Agriculture Zuru, Kebbi State, Nigeria

5. Department of Preliminary Studies, College of Science and Technology, Waziri Umaru Federal Polytechnic, Birnin Kebbi, Kebbi State, Nigeria

(Received on Date: 16 September 2020

Date of Acceptance: 12 February 2021

Date of Publish: 19 March 2021)

E-mail : dantaiadankaduna@gmail.com

\begin{abstract}
Background: Rice is an important crop for resource poor farmers across Africa and Asia. The crop is susceptible to weeds that severely reduce yields, because of their competition with the crop for moisture, nutrients, sunlight and space. Methodology: The trial was conducted in the screen house of Teaching and Research Farm of Kebbi State University of Science and Technology Aliero located at Jega during the rainy season of 2018/2019 to evaluate three selected post emergence herbicides for weed control on rice (Oryza sativa L.) in Sudan Savanna zone of Nigeria. Treatments consisted of two rice varieties (Faro 44 and Faro 52), three herbicides namely BRACER, BRACERPLUS and NOMINEEGOLD. Each of the herbicides was applied at three levels; BRACER $250 \mathrm{ml} / \mathrm{ha}, 275 \mathrm{ml} / \mathrm{ha}$ and $300 \mathrm{ml} / \mathrm{ha}$, BRACERPLUS $129 \mathrm{ml} / \mathrm{ha}, 142 \mathrm{ml} / \mathrm{ha}$ and $155 \mathrm{ml} / \mathrm{ha}$ NOMINEEGOLD $200 \mathrm{ml} / \mathrm{ha}, 300 \mathrm{ml} / \mathrm{ha}$ and $400 \mathrm{ml} / \mathrm{ha}$; with hand weeding at 4 and 8 WAS' and weedy check as control. Ten kilogram (10kg) of the soil was measured and filled into each of the sixty-six pots that were placed equidistant to one another in the screen house. Results: Thirteen (13) weed species were identified in the weed flora, among the weeds, 8 (61.54\%) were broad leaf, 4 (30.77\%) were grasses and $1(7.79 \%)$ was sedge. Application of Nomineegold at $0.3 \mathrm{I} \mathrm{ha}^{-1}$ produced higher plant establishment count, also Nomineegold at $0.4 \mathrm{I} \mathrm{ha}^{-1}$ recorded the highest weed control efficiency (WCE) of 87.96\% among the chemical weed control treatments, while Bracer plus applied at 0.142 I $\mathrm{ha}^{-1}$ produced the highest crop dry matter of $34.83 \mathrm{~g}$.Faro 52 produced higher weed control efficiency than Faro 44. Conclusion: 1. Nomineegold at $0.4 \mathrm{I} \mathrm{ha}^{-1}$ recorded the highest weed control efficiency (WCE) of $87.96 \%$ is recommended among the chemical weed control treatments, 2. Bracerplus applied at $0.142 \mathrm{I} \mathrm{ha}^{-1}$ produced the highest crop dry matter of $34.83 \mathrm{~g}$ at 10 WAS.
\end{abstract}

KEYWORDS: Evaluation, post emergence herbicide, rice varieties, sudan savanna, weed control, 


\section{INTRODUCTION}

Rice is a staple for more than $60 \%$ of the worlds' seven billion people and more than $90 \%$ of this rice is consumed in Asia (Mohanty, 2013; Chauhan et al.2014). During the year 2017 nearly 482 million metric tonnes of paddy were produced worldwide (Anon., 2018a). Although rice protein ranks high in nutritional quality among cereals, protein content is modest. The minerals, vitamins and other constituents of rice except carbohydrate are reduced by milling (Anon. 2012). In Nigeria, rice is important for several reasons including being a major contributor to internal and sub- regional trade (Oko et al., 2012). Two types of rice have been mainly cultivated in Nigeria; the African rice (Oryza glabberrima) and Asian rice (Oryza sativa) (Oko et al., 2012). In recent times, however new rice varieties have also been introduced including the West African Rice Development Association's (WARDA) hybrid rice varieties e.g. New rice for Africa (referred to as NERICA) which are inter specific hybrid between the African and the Asian rice.

Rice farmers choose varieties adapted to the region's length of growing season, soil, altitude and the depth of water in the field (Oko et al., 2012). Farmers in developing countries usually sow rice seeds in small seed beds, then transplant the seedling into flooded field that have been levelled. For this study, Faro 44 and Faro 52 were chosen because of their yield potentials and adaptability in the study Area.
Of the biotic and abiotic stresses that pose constraints to rice production, weeds are the most prominent of them across the ecologies in terms of yield reduction, labour demand and cost of control (Akinyemiju and Igori 1986; Pandey, 2009). Oyebanji and Oluyemisi (2018) cited in Islam et al (2005) that about $20 \%$ of production costs incurred by farmers are attributed to weed control during growing season. In sub-Saharan Africa, 2.2 million tonnes of rice yield is lost annually as a result of uncontrolled weeds (Oyebanji and Oluyemisi 2017). About $28-74 \%$ of rice yield is lost due to uncontrolled weed growth in transplanted lowland rice, while 48-100\% loss in upland ecosystems (Rodenburg and Johnson 2009).

Weeds are real constraints to rice production (Kwesi and De Datta, 1991). Improved weed control can increase rice yields by $15-23 \%$ depending on the agro-ecosystem (Rodenburg and Johnson 2009). As an alternative to hand weeding and other methods of controlling weeds among farmers, herbicides offer a practical and economical option for reducing crop losses and production cost (Akinyemiju and Igori, 1986; Akobundu, 1987, Kolo, 2004). The use of herbicides in rice cultivation is gaining widespread acceptance among rice farmers worldwide including Nigeria. The conventional method of weed control in rice, i.e. hand weeding is very laborious, expensive and inefficient. Chemical weed control can be considered as a better alternative (Singh, and Singh 1993). Use of chemicals to control weed has been found 
to be effective and economical (Singh and Mani, 1981). Brar and Mishra (1989) reported that chemical weeding is easier, saves time and economical as compared to hand weeding alone. Weed control using herbicides offers an advantage to save labour and money. It is regarded as cost effective method of weed control as opined by Ahmed et al, (2000). Sharma and Bhunia (1999) stated that herbicides gave significant control of weeds when applied one day after transplanting rice. Post emergence herbicides are a major tools used to control weeds in rice. The growth stage of weed species may have an effect on herbicide efficacy by influencing uptake and metabolism of herbicides (Singh and Singh, 2004). Diclofop, for example, was more effective on green foxtail (Setaria viridis (L.) Beauv.) and wild oat (Avena fatua L.) when applied at an early growth stage (Friesen et al., 1976). Conversely, trifloxysulfuron was more effective on yellow nut sedge (Cyperus esculentus L.) at late application stages (Singh and Singh 2004). Generally, the herbicide efficacy is lower when applied on bigger weeds. The herbicide degradation rate may be faster in big plants, and herbicide rates may need to be increased to achieve the desired level of control (Singh and Singh, 2004). Therefore, optimum time of herbicide application and range of herbicides may help control these weeds effectively (Gopal et al. 2010).

New herbicides for weed control in rice have been developed and there is the need to test their efficacy. The herbicides BRACER 10 SC, BRACER PLUS 16 OD and
NOMINEE GOLD 10 SC all have same active ingredient known as bispyribac at different concentration. These herbicides are selective and post emergence.

BRACER; has active ingredient as bispyribac-sodium (chemical name 2,6bis\{(4,6-dimethoxy-2-pyrimidinyl oxy\}benzoicacid $100 \mathrm{~g}$ a.i./l, it kills weed growing with rice. The herbicide is effective on sedges, grasses and broadleaves its dosage rate ranges from $250-300 \mathrm{ml} \mathrm{ha}^{-1}$, while its spray rate (L/ha in water volume) is between 160-320 I. Its time of application is 7-15days after seeding/transplanting. Its dilution rate is $10 \mathrm{ml}$ per $16 \mathrm{l}$ of water. Rate and spray volume can be increased when spraying is going to be done 10 days after planting. The herbicide has a pre-harvest interval period of 60 days.

BRACERPLUS 16 OD (160 $\mathrm{g}$ a. $\mathrm{i} / \mathrm{l}$.) is the second herbicide to be tested in this study, in addition to bispyribac sodium $4 \%$, it has an additional active ingredient which is called cyhalofop (chemical name (R)-2-[4cyano-2-fluorophenoxy] propanoic acid)butyl-12\%. The herbicide is also effective on sedges, grasses, and broadleaves weeds. Its dosage rate ranges from $129-155 \mathrm{ml} \mathrm{ha}$ 1 , its time of application is 10 days after sowing, dilution rate is $8 \mathrm{ml}$ per 161 .Both Bracer and Bracer plus are manufactured in China by Hefei Xiangyu Chemical Company Limited.

NOMINEEGOLD $10 \mathrm{SC}$. It is Post Emergence herbicide for Rice, its active ingredient is bispyribac sodium (100g a. i./l), dosage rate is $300 \mathrm{ml} \mathrm{ha}^{-1}$.The herbicide is applied when the soil is saturated with water but not flooded. Irrigation should be done 1-3 days after application and should be kept 
flooded for at least 3-4 days. Best application is achieved when weeds have between 3 and 5 leaves. The dilution rate of the herbicide is $100-200 \mathrm{l} \mathrm{ha}^{-1}$ of water for good application. It is used for the control of broadleaves, grasses and sedges in rice field.

Weed control is one of the major labour demanding farm operations in rice production; the labour requirement is very costly and may not be available at the time of need (Yawale et al., 2019). Although no single weed control method can give effective and satisfactory weed control in all ecologies, however, chemical weed control may provide a better alternative, because it is fast, cheap, easy and more effective, Lagoke, et al.(1991). The aim of the study is to evaluate three selected post emergence herbicides on rice varieties at different concentration of the herbicides, while the specific objectives are to:

determine effect of herbicides on weed suppression on growth of rice

evaluate effect of variety on weed suppression on growth of rice

iii identify weeds associated with rice growth in the Study area.

\section{MATERIALS AND METHOD \\ Experimental site}

Experiment was conducted during the dry season of 2019/2020 in the Screen house of Teaching and Research Farm of Kebbi State University of Science and Technology Aliero located at Jega (lat. $12^{0}$ 18.64' $\mathrm{N}$ : long.040 29.85', $262 \mathrm{~m}$ above sea level). The area is characterised with erratic and scanty rainfall that lasts for about 5 months (May - September) and long dry period (October - April). The climate of the area is semi-arid with average rainfall of $550-650 \mathrm{~mm}$ per annum. The relative humidity ranges from $21-47 \%$ and 51 - 79\%during the dry and rainy seasons respectively. Temperature averages between $14-30^{\circ} \mathrm{C}$ during dry season and $27-41^{\circ} \mathrm{C}$ during the rainy season (NNN, 2012).

\section{Treatments and Experimental Design}

Treatments consisted of two rice varieties (Faro 44 and Faro 52), three herbicides namely BRACER(Bispyribag sodium, chemical name 2,6-bis $\{(4,6-$ dimethoxy-2-pyrimidinyl)oxy\}benzoic acid $100 \mathrm{~g}$ a.i./I), BRACERPLUS( chemical name 2,6-bis $\{(4,6$-dimethoxy-2-

pyrimidinyl)oxy\}benzoic acid (40g a.i./l) $-4 \%$ and cyhalofop ( chemical name ( R )-2-[4cyano-2-fluorophenoxy] propanoic acid )butyl(120g a.i./I)-12\% and NOMINEE GOLD (Bispyribag sodium, chemical name 2,6bis $\{(4,6-$ dimethoxy-2-

pyrimidinyl)oxy\}benzoic acid $100 \mathrm{~g}$ a.i./l). Each of the herbicides will be applied at three levels; BRACER $250 \mathrm{ml}(25 \mathrm{~g}$ a.i./l), $275 \mathrm{ml}(27.5 \mathrm{~g}$ a.i./I) and $300 \mathrm{ml}$ (30g a.i./l), BRACERPLUS

$129 \mathrm{ml}(20.64 \mathrm{~g}$

a.i/l.), $142 \mathrm{ml}(22.72 \mathrm{~g}$ a. i./l) and $155 \mathrm{ml}(24.8 \mathrm{~g}$ a.i./l) NOMINEE GOLD 200ml(20.0 g a.i./l), $300 \mathrm{ml}(30 \mathrm{~g}$ a. i./l) and $400 \mathrm{ml}(40 \mathrm{~g}$ a.i./l); with hand weeding at 4 and 8WAS and weedy check imposed as control. The treatment was laid out in a completely randomised design with three replications.

\section{Cultural practice \\ Seed sowing}

Three seeds each were sown directly into five holes (that are $15 \mathrm{~cm}$ from one another) drilled into each plastic pot. Ten 
days after germination, the fifteen seedlings were thinned to five plants per pot. Supplying was done where poor germination of rice seedlings was observed.

\section{Watering}

Watering was done using a 10-litre watering can. Irrigation was done at as when due.

\section{Hand Weeding}

Hand weeding was done at 4 and 8Weeks After Sowing (WAS) according to treatment. Weeds were washed cleaned air dried and fresh weight was recorded and subsequently oven dried at $70{ }^{\circ} \mathrm{C}$ weighed until a constant weed dry matter weight was achieved.

\section{Fertilizer Application}

Application of 100:50:50 $\mathrm{kg} \mathrm{ha}^{-1}$ NPK was done in split doses. The first half application of $N(50 \mathrm{~kg})$, and full dose of $\mathrm{P}_{2} \mathrm{O}_{5}$ and $\mathrm{K}_{2} \mathrm{O}(50 \mathrm{~kg})$ were applied at the basal stage. The second half of $\mathrm{N}$ was applied at maximum tiller stage and at panicle initiation stage using urea $(46 \%)$ as source.

\section{Herbicide Application}

Each of the herbicides was applied at three levels; BRACER $250 \mathrm{ml} \mathrm{ha}^{-1}, 275 \mathrm{ml}$ $\mathrm{ha}^{-1}$ and $300 \mathrm{ml} \mathrm{ha}^{-1}$, BRACERPLUS $129 \mathrm{ml} \mathrm{ha}^{-}$ $1,142 \mathrm{ml} \mathrm{ha}^{-1}$ and $155 \mathrm{ml} \mathrm{ha}^{-1}$; NOMINEE GOLD 200 $\mathrm{ml} \mathrm{ha}^{-1}, 300 \mathrm{ml} \mathrm{ha}^{-1}$ and $400 \mathrm{ml} \mathrm{ha}^{-}$ 1 according to treatment at 6- weeks after sowing. Application was done once only during the cultivation period. This was done by arranging the pots with similar treatment together and herbicide will then be applied after calibration.

The rice crop was harvested at 10 weeks after sowing (WAS) manually by carefully by uprooting the crops after a soaking watering to avoid loosing the roots.

\section{Data Collection}

\section{Observation for Weed Parameters Weed Identification}

Weed incidence in the pots were assessed, identified and recorded with the aid of weed album by Akobundu and Agyakwa, (1987).

\section{Weed count}

Weed Count was taken and weeds were classified into broadleaved, grasses and sedges.

\section{Weed dry Matter}

Weed dry matter were taken after application of treatment at six weeks after sowing when the affected weeds were completely dry and at harvest to determine weed biomass after the study.

The weed samples collected will be 10 WAS oven dried at $70^{\circ} \mathrm{C}$ to a constant weight and weighed to obtain the weed dry matter.

Weed Control Efficiency (WCE): It is a derived parameter that compares different treatments of weed control on the basis of weed dry weight across them. It is an estimate of weed competition/control in crops

\section{WCE $=\frac{\text { DMC }- \text { DMT }}{\text { DMC }} \times 100$}

Where, DMC is weed dry matter in unweeded treatment and

DMT is weed dry matter in a weed control treatment (Das, 2008).

\section{Observation for Crop growth parameters} Plant Establishment count

Plant establishment count was taken 10 (ten) days after sowing (DAS). Re- 
supplying was done where poor germination of rice seedlings was observed.

\section{Phytotoxic effect on Crop}

Crop injury was scored on a scale of 0-5. 0 represents no crop killed or affected while 5 means all the crops are killed per pot.

\section{Crop dry matter at 10WAS}

The Straw yield or crop dry matter was taken from the five plants of each pot after harvesting at 10 WAS and means was calculated.

\section{Data Analysis}

Data generated was subjected to analysis of variance procedure (ANOVA) as described by Steel and Torrie (1984) and differences between treatment means were separated using Duncan Multiple Range Test (DMRT) at $5 \%$ level of probability as described by Gomez and Gomez (1984). The relationships between characters were determined through simple correlation analysis as described by Little and Hills (1978).

Results: Weed species identified in the pot experiment at Jega during the dry season of 2019/2020 and their phytosociological characters are presented in Table 1. A total of 13 weed species were identified in the pot experiment conducted in the screen house of the Teaching and Research Farm of Kebbi State University of Science and Technology Aliero located in Jega. Among the weeds 8 (61.54\%) were broad leaf, 4 (30.77\%) were grasses and 1 (7.79\%) was sedge. The results obtained showed that Digitaria horizontalis, Alternanthera sessilis, Hackelochloa granularis Vicoa leptoclada and Ludwigia hyssipifolia followed each other in their densities. Although D. horizontalis was the most frequent of all the weeds, it was followed by $A$. sessilis, $H$. granularis, $V$. leptoclada and Celosia leptostachya in that order. Although $D$. horizontalis is most frequent $(F), V$. leptoclada was on the other hand most abundant followed by $C$. leptostachya.

\section{Plant establishment}

Plant establishment count of rice as affected by weed control treatments and variety at Jega is presented in Table 2 . The result showed that the highest number of established plants was from hand weeded treatment which was followed by both applications of Bracerplus at $0.142 \mathrm{I} \mathrm{ha}^{-1}$ and $0.155 \mathrm{I} \mathrm{ha}^{-1}$, then Bracer at $0.275 \mathrm{I} \mathrm{ha}^{-1}$, Bracer at $0.31 \mathrm{ha}^{-1}$ and Bracer plus at 0.129 I ha ${ }^{-1}$. The least established plant was with the weedy check.

\section{Crop injury score}

Rice crop injury score as affected by weed control treatments and variety at Jega is presented in Table 2. Application of Nominee gold at $0.4 \mathrm{I} \mathrm{ha}^{-1}$ resulted to the highest crop injury though not statistically different from all other herbicides control treatments. The result showed that crop injury on all the herbicide treatment was comparable but there was significant difference $(p \geq 0.05)$ between the herbicide treatment and hand weeded and weedy check treatment. Both hand weeded and weedy check recorded null injury because no herbicide was applied to either treatments. There was significant difference between the rice varieties on crop injury. The effect of the treatment was significantly higher on Faro 52 than Faro 44 this may suggest that Faro 52 was more 
susceptible to the effect of the herbicide over Faro 44.

There was no interaction between weed control treatment and rice varieties during the study period.

\section{Crop dry matter at 10WAS}

Rice crop dry matter as affected by weed control treatments and variety at Jega is presented in Table 2. The result showed a significant difference in dry matter among the treatments. The hand weeded treatment produced significantly higher crop dry matter than any of the chemical weed control. treatments and the control. However applying Bracer plus at $0.142 \mathrm{I} \mathrm{ha}$ 1 produced the highest dry matter among the post emergence herbicide treatments but statistically comparable to applying Bracer plus at $0.155 \mathrm{I} \mathrm{ha}^{-1}$. Application of Bracer at $0.275 \mathrm{ha}^{-1}, 0.300 \mathrm{I} \mathrm{ha}^{-1}$, Bracer plus at $0.129 \mathrm{I} \mathrm{ha}^{-1}$, Nominee gold at 0.200 and $0.300 \mathrm{I} \mathrm{ha}^{-1}$, were all statistically similar. There was significant difference in crop dry matter between the herbicide treatments, and hand weeded treatment. There was a significant difference observed between the varieties in crop dry matter produced. Faro 44 significantly produced higher crop dry matter compared to Faro 52.

\section{Weed dry matter at 6 WAS}

Table 3 presents the influence of weed control treatments and variety on weed dry matter at 6 WAS and weed control efficiency in rice at Jega during the $2019 / 2020$ dry season. The result showed significant difference among the treatments in weed control efficiency. No significant difference was observed in weed dry matter at 6 WAS although hand weeded treatment produced the highest weed dry matter followed by (fb) Nominee gold applied at $0.300 \mathrm{I} \mathrm{ha}^{-1} \mathrm{fb}$ Nominee gold applied at $0.400 \mathrm{I} \mathrm{ha}^{-1} \mathrm{fb}$ Nominee gold applied at $0.200 \mathrm{I} \mathrm{ha}^{-1}$ in that order. Nominee gold applied at 0.3 । $\mathrm{ha}^{-1}$ produced highest weed dry matter among the post emergence herbicide applied while Bracer at $0.250 \mathrm{I} \mathrm{ha}^{-1}$ produced the least weed dry matter after the application of the treatment (i.e. 6WAS). However hand weeded treatment produced the highest weed dry matter at 6 WAS over other weed control treatments. The weedy check records no weed dry matter because no weed control treatment was applied to it.

\section{Weed control Efficiency}

Table 19 presents the result for weed control efficiency as influenced by weed control treatments and variety in rice at Jega during the 2019 dry season. The result showed applications of rates of Bracer and Bracerplus with the exception of Bracer plus at 0.155 I $\mathrm{ha}^{-1}$ had comparable weed control efficiencies with Nominee gold at 0.200 and $0.300 \quad \mathrm{l} \mathrm{ha}^{-1}$ these were significantly different with hand weeded treatment which was highest and statistically comparable to application of Nominee gold at $0.400 \mathrm{I} \mathrm{ha}^{-1}$. Among the post emergence herbicides Nominee gold applied at $0.4 \mathrm{I} \mathrm{ha}^{-1}$ produced the best weed control efficiency fb Bracer plus at $0.155 \mathrm{I} \mathrm{ha}^{-1} \mathrm{fb}$ Bracer plus at $0.142 \mathrm{I} \mathrm{ha}^{-1} \mathrm{fb}$ Nominee gold at $0.300 \mathrm{I} \mathrm{ha}^{-1}$. The herbicide that was most inefficient weed control efficiency was Bracer applied at $0.31 \mathrm{ha}^{-1}$. Hand weeded control and application of Nominee gold at 0.4 I ha-1 had similar weed control efficiency and significantly 
controlled weeds more efficiently than all other control treatments. The weedy check produced the least weed control efficiency among the weed control treatments. This is because no weed control strategy was imposed on the treatment. There was significant difference in the interaction of weed control treatments and variety at Weed control efficiency.

\section{Discussion}

\section{Influence of weed control methods on the establishment of Rice (Oryza sativa L.)}

Results from the study indicate that the influence of weed control methods did not significantly affect plant establishment. This may be attributed to the fact that treatment was not applied at the time data was taken. Treatment was applied six weeks after sowing while data was taken at ten days after sowing when the rice seeds had germinated.

\section{Crop dry matter}

Among the post emergent herbicides applied, bracer plus applied at $0.142 \mathrm{I} \mathrm{ha}^{-1}$ produced the highest crop dry matter similar to dry matter produced when bracerplus was applied at 0.155 I ha- $^{-1}$. Although hand weeded treatment produced the highest dry matter among the weed control methods, bracerplus applied at $0.142 \mathrm{I} \mathrm{ha}^{-1}$ and applied at 0.155 I ha $^{-1}$ produced higher crop dry matter than the weedy-check treatment. However, in Brasil Langaro et al., (2018) reports from his findings that the herbicide bispyribac-sodium causes the greatest injury and the greatest reduction in rice plant height.

\section{Weed control efficiency}

Weed control efficiency was comparable between the chemical weed control treatment and the hand weeded treatment. Hand weeded treatment produced highest weed control efficiency over the herbicidal treatment. The herbicidal treatments were statistically comparable between one another even with Nominee gold at $0.4 \mathrm{I} \mathrm{ha}^{-1}$ which portrayed the highest weed control efficiency (WCE) of $87.96 \%$ among the chemical weed control treatments. Application of Bracerplus at $0.155 \mid \mathrm{ha}^{-1}$ was next in efficiency $(70.16 \%)$ to Nominee gold fb Bracer at 0.25 I ha-1 $^{-1}(60.74 \%)$ and Nominee gold at $0.2 \mathrm{I} \mathrm{ha-1}^{-1}$ (60.07\%) which were comparable to one another. The treatment with least WCE was Bracer at 0.300 I ha-1 $^{-1}$ (43.86\%) fb Bracer plus at 0.129 I $\mathrm{ha}^{-1}$ (49.05\%). Nadeem et al., (2017) reports that; The best weed control (94.8-98.1\%) was achieved with two sprays $(21$ \& 40 DAS) of post emergence herbicide (bispyribac sodium) followed by single application (21 DAS) of the same herbicide which gave weed control of 77.5 to $82.3 \%$. orthosulfamuron, penoxsulam and ethoxysulfuron as post emergence herbicides were found more effective against broad leaf weeds and sedges than grasses.

\section{Conclusion:}

1. Nomineegold at $0.4 \mathrm{I} \mathrm{ha}^{-1}$ recorded the highest weed control efficiency (WCE) of $87.96 \%$ is recommended among the chemical weed control treatments. Bracerplus applied at $0.142 \mathrm{I} \mathrm{ha}^{-1}$ produced the highest crop dry matter of $34.83 \mathrm{~g}$ at 10 WAS than any other chemical weed control treatment. 
2. Faro 52 produced higher weed control efficiency than Faro 44.

3. Thirteen weed species were identified as the weed flora associated with rice growth in the study area. Among the weeds, 8 (61.54\%) were broad leaf, 4 (30.77\%) were grasses and 1 (7.79\%) was sedge. 


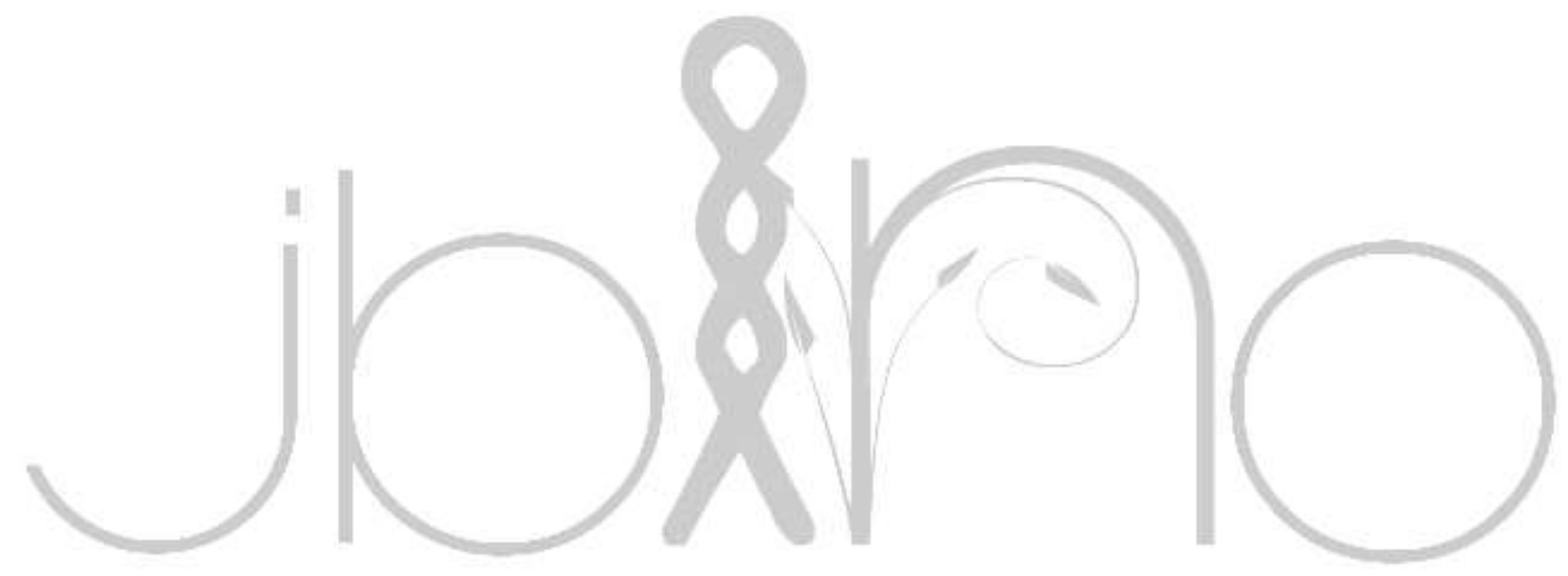


Table 1: Weeds Identified and their respective attributes in potted rice at Jega in 2019/2020 dry season

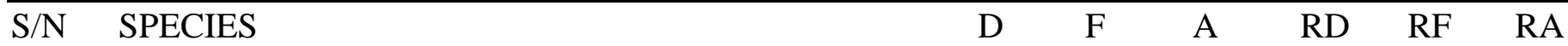
IVI

\section{Broad Leaf}

1. Alternanthera sessilis (L.)

2. Celosia leptostachya (B.)

3. Larpotea ovalifolia (S.)

4. Ludwigia abyssinica (A.)

5. Ludwigia hyssipifolia (G.)

6. Stylosanthes guianensis(A.)

7. Vicoa leptoclada (W)

8. Portulaca oleraceae (L.)

Grasses

9. Digitaria horizontalis (W)

10. Hackelochloa granularis (L)

11. Leptochloa caeraluscens (S.)

12. Setaria longiseta

(P.)

Sedges

13. Cyperus difformis (L.)

$\begin{array}{lllllll}6.50 & 45.00 & 1.23 & 8.55 & 20.30 & 6.23 & 35.08\end{array}$

$\begin{array}{lllllll}0.72 & 5.00 & 1.50 & 0.95 & 2.26 & 7.62 & 10.82\end{array}$

$\begin{array}{lllllll}0.24 & 1.67 & 1.00 & 0.32 & 0.75 & 5.08 & 6.15\end{array}$

$\begin{array}{lllllll}0.24 & 1.67 & 1.00 & 0.32 & 0.75 & 5.08 & 6.15\end{array}$

$\begin{array}{lllllll}3.13 & 1.67 & 1.44 & 4.12 & 9.77 & 7.34 & 21.23\end{array}$

$\begin{array}{lllllll}1.00 & 1.67 & 1.00 & 0.32 & 0.75 & 5.08 & 6.15\end{array}$

$\begin{array}{lllllll}3.85 & 26.67 & 2.67 & 5.07 & 12.03 & 13.54 & 30.64\end{array}$

$\begin{array}{lllllll}0.24 & 1.67 & 1.00 & 0.32 & 0.75 & 5.08 & 6.15\end{array}$

$\begin{array}{lllllll}8.66 & 60.00 & 1.09 & 0.32 & 27.07 & 5.54 & 44.01\end{array}$

$\begin{array}{lllllll}5.77 & 40.00 & 1.26 & 7.60 & 18.04 & 6.42 & 32.06\end{array}$

$\begin{array}{lllllll}0.24 & 1.67 & 1.00 & 0.32 & 0.75 & 5.08 & 6.15\end{array}$

$\begin{array}{lllllll}0.24 & 1.67 & 1.00 & 0.32 & 0.75 & 5.08 & 6.15\end{array}$

$\begin{array}{lllllll}0.24 & 1.67 & 1.00 & 0.32 & 0.75 & 5.08 & 8.15\end{array}$


Table 2: Effect of weed control treatments and variety on plant establishment count, crop injury score and crop dry matter @ 10WAS at Jega 2019/2020

Treatment Rate

\begin{tabular}{ccc} 
Plant & Crop Injury & Crop Dry matter \\
establishment & Score & 10WAS \\
Count & & $(\mathrm{g})$ \\
\hline
\end{tabular}

\begin{tabular}{lcccc}
\hline $\begin{array}{l}\text { Weed control } \\
\text { treatments }\end{array}$ & \multicolumn{3}{c}{} \\
Bracer-1 & 0.250 & 73.33 & $1.33 \mathrm{ab}$ & $20.91 \mathrm{~cd}$ \\
Bracer-2 & 0.275 & 75.56 & $1.17 \mathrm{ab}$ & $24.68 \mathrm{bcd}$ \\
Bracer-3 & 0.300 & 72.22 & $1.50 \mathrm{a}$ & $22.71 \mathrm{bcd}$ \\
Bracer plus-1 & 0.129 & 72.22 & $1.16 \mathrm{ab}$ & $26.25 \mathrm{bcd}$ \\
Bracer plus-2 & 0.142 & 76.67 & $0.50 \mathrm{ab}$ & $34.83 \mathrm{~b}$ \\
Bracer plus-3 & 0.155 & 76.67 & $0.83 \mathrm{ab}$ & $32.31 \mathrm{~b}$ \\
NomineeGold-1 & 0.200 & 70.00 & $1.50 \mathrm{a}$ & $25.4 \mathrm{bcd}$ \\
NomineeGold-2 & 0.300 & 68.89 & $1.00 \mathrm{ab}$ & $24.00 \mathrm{bcd}$ \\
NomineeGold-3 & 0.400 & 67.78 & $1.83 \mathrm{a}$ & $15.91 \mathrm{~d}$ \\
Handweeded & - & 81.11 & $0.00 \mathrm{~b}$ & $58.10 \mathrm{a}$ \\
Weedy check & - & 68.69 & $0.00 \mathrm{~b}$ & $31.30 \mathrm{bc}$ \\
SE \pm & & $\mathbf{7 . 3 9 7}$ & $\mathbf{0 . 4 1 3}$ & $\mathbf{3 . 6 9 3}$ \\
Significance & & $\mathrm{NS}$ & $*$ & $*$ \\
Variety & & & & \\
Faro 44 & & $59.59 \mathrm{~b}$ & $0.57 \mathrm{~b}$ & $33.65 \mathrm{a}$ \\
Faro 52 & & $86.46 \mathrm{a}$ & $1.39 \mathrm{a}$ & $23.87 \mathrm{~b}$ \\
SE \pm & & $\mathbf{3 . 1 4 4}$ & $\mathbf{0 . 1 7 5}$ & $\mathbf{1 . 5 6 9}$ \\
Significance & & $*$ & $*$ & $*$ \\
Interaction & & & & \\
W x V & & $\mathrm{NS}$ & $\mathrm{NS}$ & $\mathrm{NS}$ \\
\hline Means followed & & & & \\
\hline
\end{tabular}

Means followed by the same letter(s) in a treatment group are not significantly different at $5 \%$ level of significance using DMRT

$\mathrm{NS}=$ non significant 
Table 3: Effect of Weed control treatments and variety on Weed dry matter 6WAS, and Weed Control Efficiency, at Jega 2019

\begin{tabular}{|c|c|c|c|}
\hline Treatment & $\begin{array}{l}\text { Rate } \\
\left(1 \mathrm{ha}^{-1}\right)\end{array}$ & $\begin{array}{c}\text { Weed } \\
\text { DM6WAS (g) }\end{array}$ & $\begin{array}{l}\text { Weed control } \\
\text { Efficiency } \\
\text { (WCE \%) }\end{array}$ \\
\hline \multicolumn{4}{|l|}{$\begin{array}{l}\text { Weed Control } \\
\text { Treatments }\end{array}$} \\
\hline Bracer-1 & 0.250 & 0.55 & $60.74 \mathrm{c}$ \\
\hline Bracer-2 & 0.275 & 1.07 & $57.72 \mathrm{c}$ \\
\hline Bracer-3 & 0.300 & 0.97 & $43.86 c$ \\
\hline Bracer plus-1 & 0.129 & 0.63 & $49.05 c$ \\
\hline Bracer plus-2 & 0.142 & 0.87 & $62.82 \mathrm{c}$ \\
\hline Bracer plus-3 & 0.155 & 1.08 & $70.16 b c$ \\
\hline NomineeGold-1 & 0.200 & 1.20 & $56.38 \mathrm{c}$ \\
\hline NomineeGold-2 & 0.300 & 1.38 & $60.07 c$ \\
\hline NomineeGold-3 & 0.400 & 1.30 & 87.96ab \\
\hline Hand weeded & - & 1.45 & $100.00 \mathrm{a}$ \\
\hline Weedy check & - & 0.00 & 0.00 \\
\hline $\mathrm{SE} \pm$ & & 0.395 & 8.045 \\
\hline Significance & & NS & $*$ \\
\hline \multicolumn{4}{|l|}{ Variety } \\
\hline Faro 44 & in & 0.95 & 57.12 \\
\hline Faro 52 & & 1.09 & 60.83 \\
\hline $\mathbf{S E} \pm$ & & 0.168 & 3.420 \\
\hline Significance & & NS & NS \\
\hline Interaction & & & \\
\hline $\mathrm{W} \times \mathrm{V}$ & & NS & NS \\
\hline
\end{tabular}

Means followed by the same letter(s) in a treatment group are not significantly different at $5 \%$ level of significance using DMRT

$\mathrm{NS}=$ Non significant

\section{References}

Ahmed, G. J. U., A. A. Mamun, S. M. A. Hossain, A. J. Mridha and S. T. Hossain. (2000). Agro-economic study of weed control in direct seeded Aus rice in the farmers' field. Annals of Bangladesh Agriculture 8 (2): 111-118.

Akinyemiju, O. A. And Igori, O. A. (1986). An evaluation of some herbicides for preemergence control of weeds in direct seeded upland rice. Nigerian journal of Biological Sciences 1:3-11

Akobundu I. O. (1987). Weed Science in the Tropics: Principles and practices. Chichester: John Wiley and Sons.

Anonymous 2012: Botanical classification of Rice. Retrieved from: https://agropedia.iitk.ac.in/content/botanicalclassification-rice

Anonymous (2018a): Rice-Statistics and Facts. Retrieved from https://www.statista.com/topics/1443/rice/7/12/2018 Brar, L. S. and S. P. Mishra. (1989). Weed control in groundnut with pre-and postemergence herbicides. Indian Journal of Weed Science $21(1,2)$ : 16-21. 
Chauhan, B. S. Kumar, V. and Mahajan G.l 2014). Research needs for improving weed management in rice. Indian Journal of Weed Science 46 (1):1-13.

Das, T. K. (2008). Weed Science. Basics and Application. New Delhi. Jain brothers. 901 pp.

De Datta, S. K. and M. Z. Haque. (1982). Weeds, weed problems and weed control in deep water rice areas. In: Proceedings of the International Deep-water Rice Workshop, International Rice Research Institute held in Manila, Philippines. pp. 427442.

Desrosiev, H. (1999). Gelatinization Temperature of Cereal Crops, Agricultural Biotechnology, 3rd Edition, Wiley and Sons, New York231-234.

Gomez, K.A. and Gomez A. A. (1984). Statistical Procedure for Agricultural Research 2nd Edition, John Wiley and sons incorporated Singapore, pp 680

Gopal R, Jat R.K, Malik RK, et al. (2010). New Delhi, India: International Maize and Wheat Improvement Center; Direct dry seeded rice production technology and weed management in rice-based systems. Tech. Rep.

Islam, M. D. Baltazar, A. M. Manuel J. S. Martin E. C. Ramos, J. M. De Datta, S. K. and Rezaul Karim A. M.N. (2005) Tuber Production, population dynamics, and Management of Purple nutsedge in a riceonion rotation system. In Proceedings 2005, 20th Asian Pacific Weed Science Society Conference (November 7-11 ; Ho Chi Minh City Vietnam) Pp 541-549. Ho Chi Minh City Vietnam Agricultural Publishing House. In Nigerian Journal of Weed Science 31:55.

Kwesi, A. N. Surajit K. De Datta. (1991). A Handbook for weed Control in Rice,
International Rice Research Institute Philippine pp. 101 Retrieved from: http://books.google.com.ng/books..Oryza longistaminata \& $\mathrm{f}=\mathrm{false}$.

Lagoke, S.T.O Adejonwo, K. O., Ahmed, M. K. and Karikari, S. K. \{1991\}. Chemical weed control in irrigated okra in the Nigerian Suand Savanna zone. Tropical Pest Management. $37\{1\}: 91$-95.

Langaro, A.C. Agostinetto, D. Oliveira, C. Franco, J.J. Zandoná, R.R. Vargas, L. (2018): Influence of Nitrogen Fertilization on Herbicide Selectivity in Rice Planta Daninha Print version ISSN 0100-83580n-

line version ISSN 1806-9681.Planta daninha vol.36 Viçosa 2018 Epub Oct 29, 2018 https://doi.org/10.1590/s010083582018360100120.

Mohanty S. (2013). Trends in Global rice consumption. Rice Today 44-45.

Nadeem I, Muhammad U. S.Muhammad A. A. and Tahir H. A(2017):Effective Weed Management in Dry Direct Seeded Rice for Sustainable Productivity. Retrieved from: file://C:/Users/User/Documents/MyPhdfolder/\%28PDF \%29\%20Effective\%20Weed\%20Management\%20in\%20 Dry\%20Direct\%20Seeded\%20Rice\%20for\%20Sustainabl e\%20 Productivity.html.

NNN:Nigeria National News(2012). A news report by Nigeria National News(NNN). nnn.com.ng.

Oko, A. O. Ubi, B. E. Efisue, A. A. (2012). A Comparative study on Local and newly introduced Rice Varieties in Ebonyi state of Nigeria based on Selected Agronomic Characteristics. International Journal of Agriculture and Forestry 2012 2(1):11-17 DOI:10.5923/j.ijaf.20120201.03.Retrievedfro m:http://article.sapub.org/10..5923/j.ijaf.20 120201.03.html 
Oyebanji O A. and Oluyemisi A A. (2018).Weed Management Practices by Lowland Rice Farmers in the South West of Nigeria. Adv Crop Sci Tech 2018, Vol 6(3): 372 DOI: 10.4172/2329-8863.1000372. Retrieved from https://www.omicsonline.org/openaccess/weed-management-practices-by-lowland-ricefarmers-in-the-south-west-of-nigeria-2329-88631000372-102817.html 08:10a. m. 20/11/19. Pandey S. (2009). Effect of weed control on Rice cultivars under the system rice intensification (SRI). Unpublished Thesis. Tribhuvan University Institute of Agriculture and animal Science Rampur, Chitwan, Nepal.

Rodenburg, J.and Johnson, D. E. (2009). Weed management in Rice-based cropping systems in Africa. Advances in Agronomy 103:149-218

Sharma, S. K. and Bhunia, S. R. (1999). Weed management in transplanted rice (Oryza sativa) under Ghaggar flood plains of North-West Rajasthan. Indian Journal of
Agronomy 42(2): 326-330.

Singh, G. and O. P. Singh. (1993). Chemical weed control in lowland transplanted rice under .puddled condition. Annals of Agricultural Research 14: 229-231.

Singh, S. P. and V. S. Mani. (1981). Chemical weed control in rice-wheat rotation. In:Proceedings of Indian Society of Agronomy National Symposium held in Hisar, India 14-16 March 1981. pp. 62-67.

Singh, V. P. Singh, G. and Singh, M. 2004. Effect of fenoxaprop-pethyl on transplanted rice

and associated weeds. Indian Journal of Weed Science 36(3\&4): 190-192. Steel, R. D. and Torrie J. W. (1984). Principles and Procedures of Statistics. A Biometric Approach.Mc Graw hill international books Auckland pp. 663 